Annals of Plant Sciences

ISSN: 2287-688X

OPEN ACCESS

www.annalsofplantsciences.com

Research Article

\title{
Cymbidium macrorhizon (Orchidaceae): A new record for the Flora of Odisha, India.
}

Kishore Kumar Mandal ${ }^{1}$, Sudhansu Sekhar Khora ${ }^{2 *}$ \& Truptirekha Kar ${ }^{3}$

1P.G. Department of Botany, North Orissa University, Baripada, Odisha-757003, India.

2Divisional Forest Office, Bonai Forest Division, Bonaigarh, Odisha-770038, India.

${ }^{3}$ Similipal Tiger Reserve, Bhanjpur, Baripada, Odisha-757002, India.

Received: 11-08-2018; Revised: 23-08-2018; Accepted: 30-08-2018

Abstract: Cymbidium macrorbizon Lindl. is reported first time for Odisha from Koira forest of Bonai Forest Division. The correct botanical nomenclature, brief taxonomic description, with photo plate of the taxon is provided for easy identification.

Keywords: Bonai, Cymbidium, Flora, Orchidaceae, Taxon.

\section{Introduction}

The genus Cymbidium Sw. (Orchidaceae) is one of the most attractive and desirable genera of orchids in the world because of their showy and fragrant flowers. It comprises different epiphytic, lithophytic and terrestrial species having 72 species, 10 varieties, 8 subspecies and 14 natural hybrids distributed all over the world: India, Southeast Asia, China, Japan, Indonesia to Australia (Govaerts et al., 2014). Out of which 26 species, 5 subspecies and 4 varieties are found in India (Misra, 2007).

During the plant exploration in Bonai forest division of Sundargarh district, authors collected some interesting orchid specimens from Koira forest of Bonai. After critical examination of fresh and herbarium specimens including type material housed in various herbaria and perusal of literatures (Hooker, 1890; Haines, 1924; Mooney, 1950; Misra, 2004 \& 2014; Saxena \& Brahmam, 1995) these interesting specimens were identified as Cymbidium macrorbizon Lindl. Correct botanical nomenclature, brief description, with photo plate of the taxon is provided for easy identification.

\section{Taxonomic treatment}

Cymbidium macrorhizon Lindl. Gen. \& Sp. Orchid. Pl. 3: 162. 1833; Hook. f. Fl. Brit. India 6: 9. 1890; Duthie in Ann. Roy. Bot. Gard. Calcutta 9:134.t.114.1906; Babu, Herb. Fl. Dehradun: 481. 1977; Murti in Bull. Bot. Surv. India 24: 236.1983. Yoania aberrans Finet, Bull. Soc. Bot. France 47: 274. 1900. Cymbidium aberrans (Finet) Schltr., Repert. Spec. Nov. Regni Veg. Beih. 4:264.1919. Cymbidium macrorbizon var. aberrans (Finet) P.J. Cribb et Du Puy, Gen. Cymbidium, ed. 2: 330.2007 (Fig. 01).

\footnotetext{
${ }^{*}$ Corresponding Author:

Sudhansu Sekhar Khora, IFS

Divisional Forest Officer, Bonai Forest Division,

Bonaigarh, Odisha-770038, India.

Mobile No.: 7077688393

E-mail: sudhansukhora@gmail.com
}

Terrestrial saprophytic herbs, up to $20 \mathrm{~cm}$ high. Rhizome 5-20 x 0.7-1.2 cm, branched, creeping, jointed. Pseudo bulb and leaves absent. Inflorescence in lax racemes, few flowered; floral bracts 7-18 x 4-7 mm, oblong-lanceolate, acuteacuminate, entire, weakly keeled, glabrous, scarious. Flowers 3-6 cm across, pale yellow, streaked and spotted with pink, spreading; dorsal sepal 1.8-2.6 x 0.3-0.6 cm, lanceolate, entire-undulate, acuminate, spreading, 3-nerved; lateral sepals similar; petals elliptic-lanceolate, $1.5-2 \times 0.5-0.7 \mathrm{~cm}$, oblique, entire, acute, forming hood over the column, 3veined. Lip rhombic to ovate in outline 1.2-1.7 x 0.8-1.2 cm, 3 -lobed; lateral lobes small, globose, margin inflexed; mid-lobes broadly ovate, reflexed, acute; disc bi-lamellate; lamellae converging in the apical half forming a tube at the base of mid-lobe. Column $0.9-1.6 \mathrm{~cm}$ long, stout, faintly curved at the distal half, inner surface streaked with crimson; anther papillose. Pollinia 4, broadly ovate to sub globose, stipitate; stipe crescent-shaped. Capsules 3$5 \mathrm{~cm}$ long, fusiform to ellipsoidal, ridges, stalked.

Flowering \& Fruiting: June-August.

Habitat: Rare in decaying humus of moist deciduous forests at $634 \mathrm{~m}$ elevation.

Notes: This is the only species of Cymbidium in India which is of saprophytic nature. However, $C$. madidum in Australia is also saprophytic. The biology of such heterophytic plants are quite interesting and there is a need for detailed observations on the reproductive biology of these plants.

Distribution: INDIA: Arunachal Pradesh, Assam, Himachal Pradesh, Jammu \& Kashmir, Jharkhand, Manipur, Meghalaya, Mizoram, Nagaland, Odisha (Present finding), Sikkim,Uttarakhand, West Bengal: Bhutan, Burma; Cambodia; China; Japan; Nepal; Loas; Myanmar; Pakistan; Taiwan. 
Specimens examined: INDIA, Odisha (Present finding): Mendhamaruni RF, Koira, Bonai Forest Division, Sundargarh district, 29.06.2017, Mandal \& Kar 847 (CAL); Jharkhand: Netarhal, Latehar, 11.09.2004, P. Kumar 0411190 (WII); Meghalaya: Shillong, woodlands, 16.06.1970, B. Krishna 38395 (ASSAM); Mairang forest, 03.07.1980, A.S.
Chauhan 62376 (ASSAM); Nagaland: Naga Hills, June 1936, N.L. Bor 21078 (ASSAM); Uttarakhand: Near Mussoorie, on Banog, 24.07.1899, P.W. Mackinnon 22717 (DD); Near chorela sal forest, Dehradun, 20.06.2003, J.S. Jalal 13767 (WII).

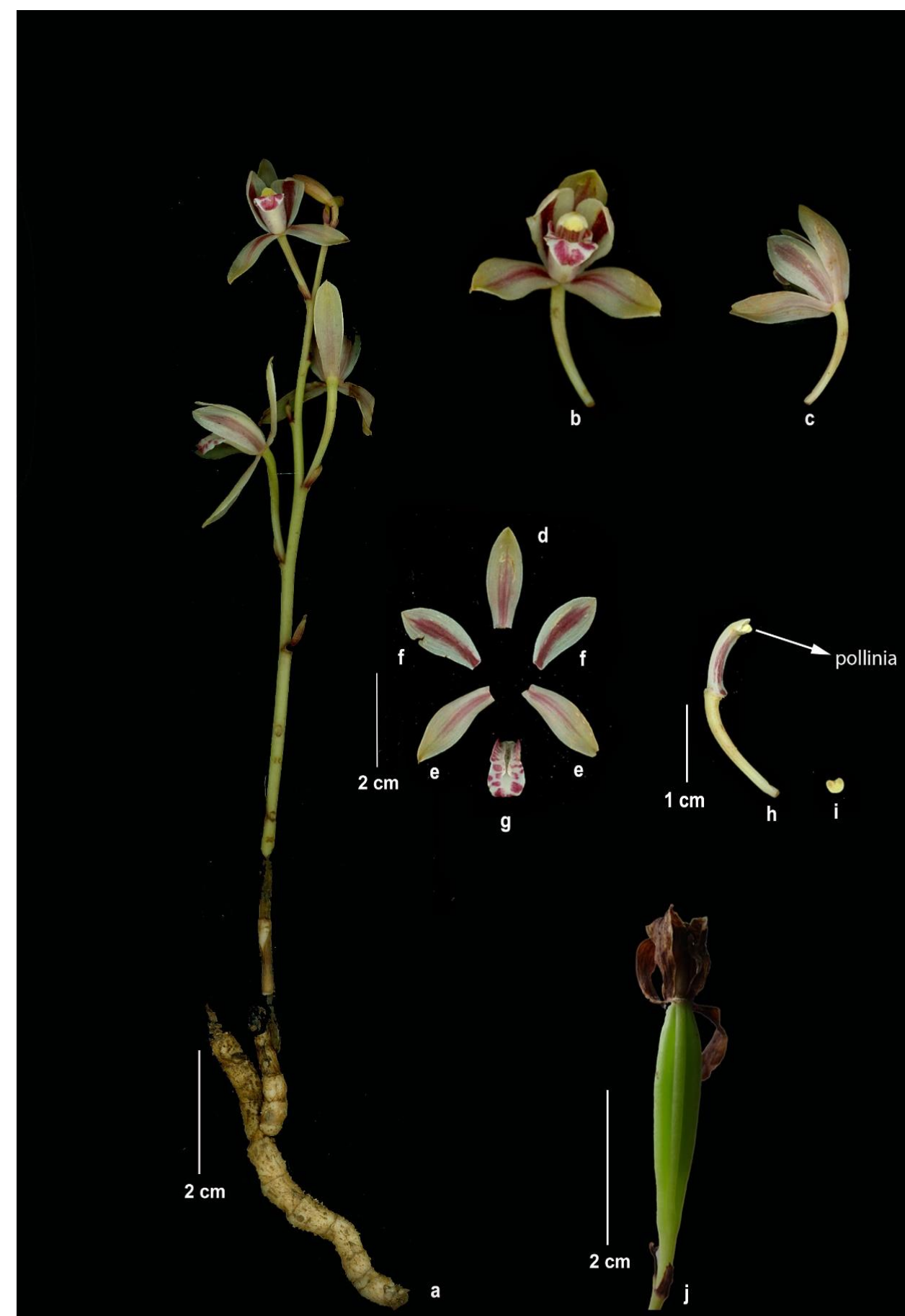

Fig. 01 : Cymbidium macrorhizon Lindl. a: Habit. b: Flower in front view. c: Flower in side view. d: Dorsal sepal. e: Lateral sepals. f: Petals. g: Lip. h: Column, Pedicel \& Ovary. i: Anther cap. j: Capsule 


\section{Acknowledgements}

The authors are thankful to Dr. Debabrata Swain, IFS, Principal Chief Conservator of Forests \& HoFF for his active support during the survey. The authors are extend their gratitude to Dr. Sandeep Tripathy, IFS, PCCF (Wildlife) \& Chief Wildlife Warden for his kind permission to carry out the field work and Mr. Lingaraj Otta, IFS, Regional Chief Conservator of Forest, Rourkela Circle for his kind co-operation. The authors are also grateful to Dr. Paramjit Singh, Director, Botanical Survey of India, Kolkata for permission to consult herbaria and library.

\section{References}

1. Govaerts, R., Dransfield, J., Zona, S.F., Hodel, D.R. \& Henderson, A., World Checklist of Orchidaceae. Facilitated by the Royal Botanic Gardens, Kew. Published on the Internet: http://apps.kew.org./wcsp/, 2014, Retrived on 2018/03/01.

2. Haines, H.H. The Botany of Bihar and Orissa. Part VI, Adlard and Sons, London. 1924, 1150- 1182.
3. Hooker, J.D. The Flora of British India. Vol 6. L. Reeve \& Co., London, 1890, 1-792.

4. Misra, S. Orchids of Orissa. Bishen Singh Mahendra Pal Singh, Dehra Dun, 2004, 1-774.

5. Misra, S. Orchids of India: A glimpse. Bishen Singh Mahendra Pal Singh, Dehra Dun, 2007, 1-402.

6. Misra, S. Orchids of Odisha: A handbook. Bishen Singh Mahendra Pal Singh, Dehra Dun, 2014, 1-424.

7. Mooney H.F. Supplements to the Botany of Bihar and Orissa. Catholic Press, Ranchi, 1950.

8. Saxena, H.O. \& Brahmam, M. The Flora of Orissa. Vol. 3. Orissa Forest Development Corporation, Ltd. Bhubaneswar, 1995, 1323-2008.

\section{Cite this article as:}

Kishore Kumar Mandal, Sudhansu Sekhar Khora \& Truptirekha Kar. Cymbidium macrorbizon (Orchidaceae): A new record for the Flora of Odisha, India. Annals of Plant Sciences 7.9 (2018) pp. 2415-2417.

do $\mathrm{http://dx.doi.org/10.21746/aps.2018.7.9.2}$

Source of support: Forest \& Environment Department, Government of Odisha.

Conflict of interest: Nil. 